\title{
The Relationships Between Population and Development
}

\section{https://kependudukan.lipi.go.id/id/kajian-kependudukan/kemiskinan/977-the-} relationships-between-population-and-development

\begin{abstract}
Population plays a vital role in the development of the country. Through various aspects such as the size of the population, geographical spread, population density, the composition of the age, sex, education and health, as well as its growth rate, it is clear that the population could affect development growth, both in the sense of negative or positive. The relationship between population and development is cause and effect in both directions, and development can affect the population and population can affect development (Gould, 2009). The population is an essential asset in development. The reflective relationships between population and development have always been famous for a human group (Gould, 2009: 20). The quality of population will impact the development process in a country. Population quality is closely related to the population of a nation's development to process the existing natural resources, to meet the necessities of life and improve their welfare. Indicators of the quality of human resources can be seen from several aspects such as level of education, income and health levels. The quality of the population does not only affect national development at this time. Development of a nation is affected by the conditions of the population in the past. In other words, the condition of the population will affect development.
\end{abstract}

The quality of the population has a dominant influence on the development of a nation. Human resources also determine the success of national development through the number and quality of the population. A large population is a potential market to produce results, while the quality of the population determines how much productivity. Simon (1977) argued that the effect of population growth on development could be divided into two. First, population growth in the short term it is a negative influence. Second, in the long term, precisely the population growth has a positive effect on development (Simon, 1977).

The negative effect of population growth in development is the number and quality of the population. Most of developing countries experiencing population problems such as increasing population growth, population distribution between islands and regions that are not evenly distributed, the composition of the population that are less favourable (the number of young people), and urbanization is high. The development orientation in the high economic growth will lead to an increase in income inequality. The industrialization and liberalization that is too fast it will increase efficiency and productivity, but it also increases the number of unemployed and underemployed. The number of the total population is a burden for the government. To overcome this problem, the government needs to control the population with family planning program and reduce the fertility rate.

In the other hand, the population had a positive effect on development. Development of the population is tailored to the potential development and condition of the existing population. Citizens should be a central point in the development process. More emphasis on the development of human resources quality improvement compared to mere infrastructure development. Large population, if followed by an adequate quality of the population, will be a stimulus for economic growth. Impact of changes in population dynamics will be felt in the long term.

Written by: Inayah Hidayati - Research Center for Population LIPI

\section{References:}

Simon, J. L. (1977). The economics of population growth.

W.T.S. Gould (2009), Population and development, Routledge Perspectives on Development. 